\title{
Cognitive Ergonomics: Driving Safety Engineering Analysis using the SHERPA Method and the HEART Methods Approach
}

\author{
Rullie Annisa ${ }^{2 *}$, Weny Findiastuti ${ }^{1}$ Rachmad Hidayat $^{1}$, and Rifky Yusron $^{2}$ \\ ${ }^{1}$ Department of Industrial Engineering, University of Trunojoyo Madura, Bangkalan, Indonesia \\ ${ }^{2}$ Department of Mechanical Engineering, University of Trunojoyo Madura, Bangkalan, Indonesia
}

\begin{abstract}
One factor driving accident that Human error. To minimize the occurrence of traffic accidents on the toll Suramadu necessary to analyze the driving safety engineering. There are nine drive-based HTA activities include Deselerate, Adding Speed, Stable, check behind the vehicle, check the vehicle in front, view mirrors, Lit beacon lights, Precede, yet precedes. Method SHERPA and HEART methods approach that aims to find great value HEP so that the most dominant factor in traffic accidents due to the driver can be determined, based on such things can be done in driving safety engineering. Based on the identification and analysis of the results obtained HEP value is 1,488 , or $149 \%$, for the types of errors in point 2.3 .3 which precedes activity with limited time item, the risk does not fit that predicted, and requires a decision that depends on the ability of the rider so that needs to be done improvement in the behavior of motorists to pay attention to safety driving such as traffic warning symbol.
\end{abstract}

Keyword : SHERPA Method, HEART Methods, Safety Driving

\section{Introduction}

Is the longest toll Surabaya Madura (Suramadu) National Bridge connecting the island of Java (Surabaya) and Madura Island in (Bangkalan) with a length of $5,438 \mathrm{~m}$. Is one of the longest toll freeway traffic at high risk such as traffic accidents. Traffic accidents occur due to various factors, such as nature and the environment, infrastructure, and human error. Human error is an error or failure committed by motorists who deviate from predetermined rules, irregularities committed by the driver that causes frequent traffic accidents occur. Some of the factors that affect human error include fatigue, age, health, the environment noisy or messy, and so forth [1]. One approach is to identify the human error that caused a traffic accident on the longest toll Suramadu Sytematic method is to approach Reductionand Prediction Human Error Approach (SHERPA) and methods Human Error Assessment and Reduction Technique (HEART).

\subsection{Human Error and Accident}

Human error is often defined as the natural thing to happen to humans, but has a detrimental impact on productivity. Human errors often occur in the production process as well as other parts of the company, such as typing errors when human letter using a typewriter, an error reading information on when the body is tired. Human error can be minimized using good management and structured work, maintain body condition in order to stay focused while doing the job [1]. Accident is a condition involving the victim, both life and property by accident. According to Pasal 93 in Peraturan Pemerintah No. 43 Tahun 1993 that the accident is an event in the unexpected and unexpectedly and unintentionally involving road users and result in loss of property. Accidents often occur due to negligence of humans in terms of both road users and facility providers. Accidents can be caused by several sources that lack of awareness of the man of regulations on the highway, the lack of adequate facilities, the lack of police fleets, and the condition of the road it self [7].

\subsection{Human Reliability Assessment}

Human reliability is an ability possessed by individuals in completing a job or a duty charged in a system with a predetermined time. Human reliability in a working system, can be judged from the least errors that occur due to the fault of the individuals themselves. Criteria for a reliable man in a working system is when all of the functions that have been set, done well under the conditions stated previously [3]. Human reliability assessment was done to help the system designer, manager, or operator in finding ways to improve the reliability of work, job security, and profitability of a technology system. The conduct an assessment of the reliability of a human, it is expected to be able to see a hazard that may arise during work operations as well as

\footnotetext{
* Corresponding author : rullie.annisa@trunojoyo.ac.id
} 
help determine the most appropriate way to reduce the risk will occur and affect the reliability of the human [12].

\subsection{SHERPA Method}

SHERPA method is a qualitative method for analyzing human reliability in a system. SHERPA method can be used to analyze the potential for human error associated with the ability or behavior of the operator. SHERPA is the basic input method outlined taks basic level using Hirarchical Task Analysis (HTA). The advantage of using SHERPA method is that it helps the system designer, manager, or operator in finding ways to improve the reliability of work, job security, and profitability of a technology system [6]. Here are the steps for analyzing human reliability using SHERPA.

1. Make Hirarchical Task Analysis

Manufacture Hirarchical Task Analysis (HTA) is made to describe the tasks and sub-tasks performed in the production process.

2. Identify Human error

Human error identification process is to determine the error mode each task performed.

3. Analysis of the consequences of errors and ordinal probability of error.

Consequences of error is the result obtained when the error occurs in a process. Error probability ordinal analysis is the process of assessment of the error that occurred, the error that has a high possibility of error is high and which has a low possibility is low.

4. Analysis Improvement Strategies.

Analysis of the improvement strategy is a solution that can be used to prevent human error which may occur in a system

\subsection{HEART Method}

HEART method is an error quantification method for human error mengientifikasi to see the most dominant factor in creating an error. The occurrence of error is influenced not only by one factor alone, such as operator kedaan weary and heavy workloads. HEART method will mengeyampingkan error factor whose value is smaller than other factors, determining the most dominant factor is to look at the factors that have a value of HEP (Human Error Probability) is the highest [6]. Here are the steps for analyzing human reliability using methods HEART.

1. Grouping in the Generic Task Type

Each task in the production process compared to the category of taks to determine the value of human unreability.

2. Identification of Producing Error Value Condition (EPC).

Great determination condition producing error values grounded by determining factors that resulted in the error.

3. Determine Proportion of Effect
Value of the proportion of effect diapatkan from interviews with specialists who understand the process as a whole. Assessment is done on each task performed.

4. Calculating the Effect Assessed

Effect Assessed calculations performed to calculate the value of Human Error Probability, following formula is used to calculate Assessed Effect

$$
A E_{1}(E P C-1) .(P O E)+1
$$

5. Calculating the Value of Human Error Probability Human error probability value will determine the tasks that have incidence highest human error. Here is the formula used to calculate the value of HEP.

$$
\text { HEP=Assessed Effect } x \text { Human Unreability }
$$

\section{Research Approach}

This research was conducted at the toll Surabaya Madura (Suramadu). Components of toll items examined are motorists on human error when going past the cross, while stale rigorous environment is a warning sign that appears along the highway Surabaya Madura. Identification of human error begins by describing the task of motorists using the HTA which is about the behavior of motorists while crossing the highway. The next step identifies human error that occurs at every level by using SHERPA and HEART. Based on the error that had been predicted, made the representation of human error by using a fault tree diagram. As for the human error that is represented is the toll of traffic accidents in Surabaya Madura, which is divided into 3 include:

1. A motor vehicle that is picking up speed vehicle speed suddenly.

2. A motor vehicle that reduces the speed of the vehicle suddenly.

3. The existence of a motor vehicle which is still not reduce or increase the speed while driving.

4. The presence of vehicles that do not turn on when the sign will precede.

The results of the identification of the fault tree diagram of human error resulting from motorists who can cause an accident on the highway traffic. Furthermore, the methods HEART calculated value of the probability of occurrence of each such human.

\section{Result And Analysis}

Hirarchical task analysis (HTA) is used to describe and analyze how a driver interacts with the system or with other personnel who are in the system. HTA is done to simplify the process of identifying human error that occurred in the longest toll Suramadu. There is a major task which will then be at the breakdown in sub-tasks or the basic tasks of an activity, as illustrated in Figure 1. Based on the obtained HTA there are nine activity in driving activity. Of the nine subsequent drive activity in human error identification based on table 1 is the 
category of error SHERPA [9]. This is to determine the error mode of each activity or task being performed. Following the identification of human error as listed in Table 1.

After the error mode on each activity is identified, then the consequences of error analysis and probability of error. This is done to know the result obtained from the error while driving, such as on the activity of error decelerate have consequences that do not know if there are other vehicles that will precede Potentially that could cause an accident with a probability of error is the medium category. Based on the identification of human error, error mode and consequence analysis error and error probability is needed repair strategy to minimize and even prevent the occurrence of human error which may occur in driving as set out in Table 2. Sample strategy 1.1.1 improvement in activity that sets the speed stably while Motorists driving and saw a maximum limit signs every $\mathrm{km} / \mathrm{h}$.

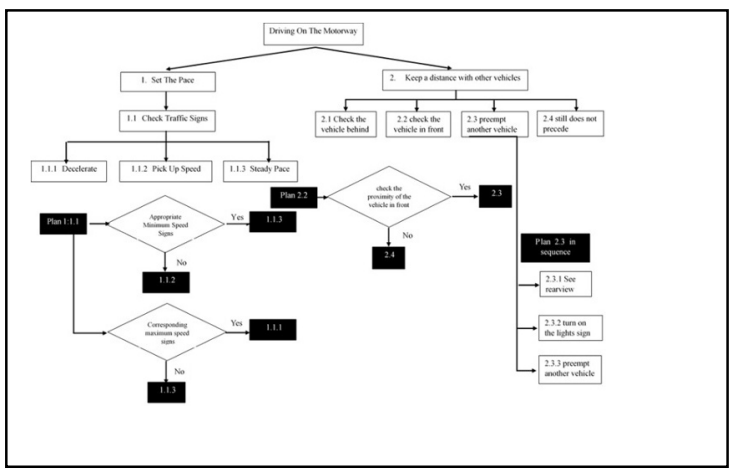

Fig 1. Hirarchical Task Analysis

Table 1. Identification of human error.

\begin{tabular}{|c|c|c|c|}
\hline No & Activity & Error mode & $\begin{array}{l}\text { Description of } \\
\text { the error }\end{array}$ \\
\hline 1.1 .1 & Decelerate & $\begin{array}{l}\text { Activity Not } \\
\text { done }\end{array}$ & $\begin{array}{l}\text { Does not reduce } \\
\text { the speed of the } \\
\text { vehicle }\end{array}$ \\
\hline 1.1 .2 & $\begin{array}{l}\text { Adding } \\
\text { speed }\end{array}$ & $\begin{array}{c}\text { Activity Not } \\
\text { done }\end{array}$ & $\begin{array}{l}\text { Do not add to the } \\
\text { vehicle's speed }\end{array}$ \\
\hline 1.1 .3 & $\begin{array}{l}\text { Steady } \\
\text { pace }\end{array}$ & $\begin{array}{l}\text { Activity Not } \\
\text { done }\end{array}$ & $\begin{array}{c}\text { Does not increase } \\
\text { or decrease the } \\
\text { speed }\end{array}$ \\
\hline 2.1 & $\begin{array}{l}\text { Check the } \\
\text { vehicle } \\
\text { behind }\end{array}$ & $\begin{array}{l}\text { Activity Not } \\
\text { done }\end{array}$ & $\begin{array}{l}\text { Do not check the } \\
\text { conditions behind } \\
\text { the vehicle }\end{array}$ \\
\hline 2.2 & $\begin{array}{l}\text { Check the } \\
\text { vehicle in } \\
\text { front }\end{array}$ & $\begin{array}{l}\text { Activity Not } \\
\text { done }\end{array}$ & $\begin{array}{l}\text { Do not check the } \\
\text { conditions behind } \\
\text { the vehicle }\end{array}$ \\
\hline 2.3 .1 & $\begin{array}{c}\text { See } \\
\text { rearview }\end{array}$ & $\begin{array}{l}\text { Activity Not } \\
\text { done }\end{array}$ & $\begin{array}{l}\text { Do not check the } \\
\text { rear view mirror } \\
\text { while driving }\end{array}$ \\
\hline 2.3 .2 & $\begin{array}{l}\text { Turn on } \\
\text { the lights } \\
\text { sign }\end{array}$ & $\begin{array}{l}\text { Action carried } \\
\text { out too fast or } \\
\text { slow }\end{array}$ & $\begin{array}{l}\text { Sign lights } \\
\text { turning on and } \\
\text { off too fast or } \\
\text { slow }\end{array}$ \\
\hline 2.3 .3 . & Precede & $\begin{array}{c}\text { Activity Not } \\
\text { done }\end{array}$ & $\begin{array}{l}\text { Not precedes } \\
\text { while driving }\end{array}$ \\
\hline 2.4 & $\begin{array}{l}\text { Still not } \\
\text { Precede }\end{array}$ & $\begin{array}{l}\text { Activity Not } \\
\text { done }\end{array}$ & $\begin{array}{l}\text { Still not precede } \\
\text { while driving }\end{array}$ \\
\hline
\end{tabular}

HEART analysis was conducted to determine the probability of human error value of each task on a basic level when driving on the Toll Road. Based on the comparison drive activity into the category of tasks [6], do the grouping in order to obtain the Generic Task Type unreability human value of 0:02 in activity 1.1.1, while activity 2.3 .2 and 2.3 .3 of 0.0004 and $0: 16$ as described in the table 3.

Based on the activities undertaken in the process of driving on the largest Toll Suramadu the main activity that regulates the speed and maintain distance from other people. Next will be at the breakdown in sub-tasks or task basis of an activity [17], in order to obtain nominal EPCs, Proportion of Effect, and Effect Assessed highest on items limited time on each activity at $10,0.5$ or 0.3 , and 5.5 , so that the value of the contribution on items limited time by $53 \%$ to $81 \%$ as shown in table 4.

Table 2. Analysis of the consequences of error, error probability ordinal and Improvement Strategies.

\begin{tabular}{|c|c|c|c|}
\hline No & Consequences & $\begin{array}{c}\text { Error } \\
\text { probability }\end{array}$ & $\begin{array}{c}\text { Improvement } \\
\text { Strategies }\end{array}$ \\
\hline 1.1 .1 & $\begin{array}{l}\text { Do not know if } \\
\text { there are other } \\
\text { vehicles that } \\
\text { will precede } \\
\text { that could } \\
\text { potentially } \\
\text { cause an } \\
\text { accident }\end{array}$ & Medium & $\begin{array}{c}\text { Set the speed } \\
\text { stably while } \\
\text { driving and saw } \\
\text { motorists } \\
\text { maximum limit } \\
\text { signs every } \mathrm{km} / \mathrm{h}\end{array}$ \\
\hline 1.1 .2 & $\begin{array}{l}\text { Do not know if } \\
\text { there are other } \\
\text { vehicles that } \\
\text { will stop that } \\
\text { could } \\
\text { potentially } \\
\text { cause an } \\
\text { accident }\end{array}$ & High & $\begin{array}{l}\text { Arranging a safe } \\
\text { distance when } \\
\text { driving with a } \\
\text { minimum } \\
\text { interval of one } \\
\text { rider around the } \\
\text { vehicle in front }\end{array}$ \\
\hline 1.1 .3 & $\begin{array}{l}\text { Resulting in } \\
\text { the vehicle } \\
\text { approximately } \\
\text { participate } \\
\text { braked } \\
\text { suddenly and } \\
\text { the potential } \\
\text { occurrence of } \\
\text { accidents } \\
\text { between } \\
\text { vehicles }\end{array}$ & High & $\begin{array}{c}\text { Increase } \\
\text { awareness brake } \\
\text { arrangement } \\
\text { with both when } \\
\text { driving }\end{array}$ \\
\hline 2.1 & $\begin{array}{l}\text { Do not pay } \\
\text { attention to the } \\
\text { conditions } \\
\text { around the } \\
\text { vehicle when } \\
\text { preceded that } \\
\text { could } \\
\text { potentially } \\
\text { cause an } \\
\text { accident }\end{array}$ & High & $\begin{array}{c}\text { Set the speed } \\
\text { stably when } \\
\text { mendahulungi } \\
\text { other riders and } \\
\text { motorists see the } \\
\text { maximum limit } \\
\text { signs every } \mathrm{km} / \mathrm{h}\end{array}$ \\
\hline 2.2 & $\begin{array}{l}\text { Do not pay } \\
\text { attention to the } \\
\text { condition of } \\
\text { the vehicle in } \\
\text { the rear so that } \\
\text { driving at will }\end{array}$ & Medium & $\begin{array}{l}\text { Checking the } \\
\text { rearview well } \\
\text { when driving }\end{array}$ \\
\hline
\end{tabular}




\begin{tabular}{|c|c|c|c|}
\hline & $\begin{array}{c}\text { and could } \\
\text { potentially lead } \\
\text { to accidents }\end{array}$ & & \\
\hline 2.3 .1 & $\begin{array}{l}\text { Do not pay } \\
\text { attention when } \\
\text { the rearview } \\
\text { mirror will } \\
\text { precede other } \\
\text { vehicles and } \\
\text { automatically } \\
\text { does not know } \\
\text { the conditions } \\
\text { surrounding } \\
\text { that could } \\
\text { potentially } \\
\text { cause an } \\
\text { accident }\end{array}$ & Medium & $\begin{array}{c}\text { Raising } \\
\text { awareness of the } \\
\text { use of rear view } \\
\text { mirror to detect } \\
\text { the condition } \\
\text { around }\end{array}$ \\
\hline 2.3 .2 & $\begin{array}{l}\text { Other vehicles } \\
\text { not know if } \\
\text { there are riders } \\
\text { who will } \\
\text { precede that } \\
\text { could } \\
\text { potentially } \\
\text { cause an } \\
\text { accident }\end{array}$ & High & $\begin{array}{l}\text { Arranging a safe } \\
\text { distance when } \\
\text { driving with the } \\
\text { driver about } \\
\text { overtaking }\end{array}$ \\
\hline 2.3.3. & $\begin{array}{l}\text { Resulting in } \\
\text { another vehicle } \\
\text { that exists } \\
\text { around an } \\
\text { abrupt halt } \\
\text { when there is a } \\
\text { rider that } \\
\text { would precede } \\
\text { that could } \\
\text { potentially } \\
\text { cause an } \\
\text { accident }\end{array}$ & High & $\begin{array}{c}\text { Increase } \\
\text { awareness brake } \\
\text { arrangement } \\
\text { with both when } \\
\text { drivingDo not } \\
\text { add to the } \\
\text { vehicle's speed }\end{array}$ \\
\hline 2.4 & $\begin{array}{l}\text { Not preempt } \\
\text { another vehicle } \\
\text { so as to keep } \\
\text { order on the } \\
\text { road }\end{array}$ & High & $\begin{array}{c}\text { Increase } \\
\text { awareness brake } \\
\text { arrangement } \\
\text { with both when } \\
\text { driving }\end{array}$ \\
\hline
\end{tabular}

Table 3. Effect Assested and Contributions

\begin{tabular}{|c|c|c|c|}
\hline No & Activity & $\begin{array}{l}\text { Nominal } \\
\text { EPCs }\end{array}$ & $\begin{array}{c}\text { Proportion of } \\
\text { Effect }\end{array}$ \\
\hline 1.1 .1 & Decelerate & $\mathrm{E}$ & 0.02 \\
\hline 1.1 .2 & Adding speed & E & 0.02 \\
\hline 1.1 .3 & Steady pace & $\mathrm{D}$ & 0.02 \\
\hline 2.1 & $\begin{array}{c}\text { Check the } \\
\text { vehicle behind }\end{array}$ & E & 0.02 \\
\hline 2.2 & $\begin{array}{c}\text { Check the } \\
\text { vehicle in front }\end{array}$ & E & 0.02 \\
\hline 2.3 .1 & See rearview & E & 0.02 \\
\hline 2.3 .2 & $\begin{array}{l}\text { Turn on the } \\
\text { lights sign }\end{array}$ & G & 0.0004 \\
\hline
\end{tabular}

\begin{tabular}{|c|c|c|c|}
\hline 2.3 .3$. & Precede & C & 0.16 \\
\hline 2.4 & $\begin{array}{l}\text { Still not } \\
\text { precede }\end{array}$ & D & 0.02 \\
\hline
\end{tabular}

Table 4. Activity EPC Description

\begin{tabular}{|c|c|c|c|}
\hline No & Activity & EPC & Description \\
\hline 1.1 .1 & Decelerate & $\begin{array}{c}2 \\
12 \\
24\end{array}$ & $\begin{array}{l}\text { Limited time } \\
\text { Risk does not fit that } \\
\text { predicted } \\
\text { Requires decision making } \\
\text { that relies on the experience } \\
\text { and ability of the rider }\end{array}$ \\
\hline 1.1 .2 & $\begin{array}{l}\text { Adding } \\
\text { speed }\end{array}$ & $\begin{array}{c}2 \\
12 \\
24\end{array}$ & $\begin{array}{l}\text { Limited time } \\
\text { Risk does not fit that } \\
\text { predicted } \\
\text { Requires decision making } \\
\text { that relies on the experience } \\
\text { and ability of the rider }\end{array}$ \\
\hline 1.1 .3 & $\begin{array}{l}\text { Steady } \\
\text { pace }\end{array}$ & $\begin{array}{c}2 \\
12 \\
24\end{array}$ & $\begin{array}{l}\text { Limited time } \\
\text { Risk does not fit that } \\
\text { predicted } \\
\text { Requires decision making } \\
\text { that relies on the experience } \\
\text { and ability of the rider }\end{array}$ \\
\hline 2.1 & $\begin{array}{l}\text { Check the } \\
\text { vehicle } \\
\text { behind }\end{array}$ & $\begin{array}{c}2 \\
17 \\
24\end{array}$ & $\begin{array}{l}\text { Limited time } \\
\text { Cheking less intensive } \\
\text { Requires decision making } \\
\text { that relies on the experience } \\
\text { and ability of the rider }\end{array}$ \\
\hline 2.2 & $\begin{array}{l}\text { Check the } \\
\text { vehicle in } \\
\text { front }\end{array}$ & $\begin{array}{c}2 \\
17 \\
24\end{array}$ & $\begin{array}{l}\text { Limited time } \\
\text { Cheking less intensive } \\
\text { Requires decision making } \\
\text { that relies on the experience } \\
\text { and ability of the rider }\end{array}$ \\
\hline 2.3 .1 & $\begin{array}{c}\text { See } \\
\text { rearview }\end{array}$ & $\begin{array}{c}2 \\
15 \\
\\
24\end{array}$ & $\begin{array}{c}\text { Limited time } \\
\text { Motorists are not } \\
\text { accustomed to seeing the } \\
\text { rearview } \\
\text { Requires a decision that } \\
\text { depends on the rider's ability }\end{array}$ \\
\hline 2.3 .2 & $\begin{array}{l}\text { Turn on } \\
\text { the lights } \\
\text { sign }\end{array}$ & $\begin{array}{c}2 \\
23\end{array}$ & $\begin{array}{c}\text { Limited time } \\
\text { The non-functioning lights } \\
\text { sign }\end{array}$ \\
\hline 2.3.3. & Precede & $\begin{array}{c}2 \\
12 \\
24\end{array}$ & $\begin{array}{l}\text { Limited time } \\
\text { Risk does not fit that } \\
\text { predicted } \\
\text { Requires decision making } \\
\text { that relies on the experience } \\
\text { and ability of the rider }\end{array}$ \\
\hline 2.4 & $\begin{array}{l}\text { Still not } \\
\text { precede }\end{array}$ & $\begin{array}{c}2 \\
12 \\
24\end{array}$ & $\begin{array}{l}\text { Limited time } \\
\text { Risk does not fit that } \\
\text { predicted } \\
\text { Requires decision making } \\
\text { that relies on the experience } \\
\text { and ability of the rider }\end{array}$ \\
\hline
\end{tabular}


Table 5. Effect Assested and Contributions

\begin{tabular}{|c|c|c|c|c|c|}
\hline No & Activity & $\begin{array}{c}\text { Nominal } \\
\text { EPCs }\end{array}$ & $\begin{array}{l}\text { Propor } \\
\text { tion of } \\
\text { Effect }\end{array}$ & $\begin{array}{c}\text { Effect } \\
\text { Assess } \\
\text { ed }\end{array}$ & $\begin{array}{c}\text { Con } \\
\text { trib } \\
\text { utio } \\
\text { n }\end{array}$ \\
\hline 1.1 .1 & Decelerate & $\begin{array}{c}10 \\
4 \\
1.6\end{array}$ & $\begin{array}{l}0.5 \\
0.5 \\
0.2\end{array}$ & $\begin{array}{c}5.5 \\
2.5 \\
1.12\end{array}$ & $\begin{array}{l}60 \% \\
27 \% \\
12 \%\end{array}$ \\
\hline 1.1 .2 & $\begin{array}{l}\text { Adding } \\
\text { speed }\end{array}$ & $\begin{array}{c}10 \\
4 \\
1.6\end{array}$ & $\begin{array}{l}0.5 \\
0.5 \\
0.2\end{array}$ & $\begin{array}{c}5.5 \\
2.5 \\
1.12\end{array}$ & $\begin{array}{l}60 \% \\
27 \% \\
12 \%\end{array}$ \\
\hline 1.1 .3 & $\begin{array}{l}\text { Steady } \\
\text { pace }\end{array}$ & $\begin{array}{c}10 \\
4 \\
1.6\end{array}$ & $\begin{array}{l}0.5 \\
0.5 \\
0.2\end{array}$ & $\begin{array}{l}5.5 \\
2.5 \\
1.12\end{array}$ & $\begin{array}{l}60 \% \\
27 \% \\
12 \%\end{array}$ \\
\hline 2.1 & $\begin{array}{l}\text { Check the } \\
\text { vehicle } \\
\text { behind }\end{array}$ & $\begin{array}{c}10 \\
3 \\
1.6\end{array}$ & $\begin{array}{l}0.3 \\
0.5 \\
0.4\end{array}$ & $\begin{array}{c}3.7 \\
2 \\
1.24\end{array}$ & $\begin{array}{l}53 \% \\
29 \% \\
18 \%\end{array}$ \\
\hline 2.2 & $\begin{array}{l}\text { Check the } \\
\text { vehicle in } \\
\text { front }\end{array}$ & $\begin{array}{c}10 \\
3 \\
1.6\end{array}$ & $\begin{array}{l}0.3 \\
0.5 \\
0.4\end{array}$ & $\begin{array}{c}3.7 \\
2 \\
1.24\end{array}$ & $\begin{array}{l}53 \% \\
29 \% \\
18 \%\end{array}$ \\
\hline 2.3 .1 & $\begin{array}{c}\text { See } \\
\text { rearview }\end{array}$ & $\begin{array}{c}10 \\
3 \\
1.6\end{array}$ & $\begin{array}{l}0.5 \\
0.2 \\
\\
0.3\end{array}$ & $\begin{array}{c}5.5 \\
1.4 \\
1.18\end{array}$ & $\begin{array}{l}68 \% \\
17 \% \\
15 \%\end{array}$ \\
\hline 2.3 .2 & $\begin{array}{l}\text { Turn on } \\
\text { the lights } \\
\text { sign }\end{array}$ & $\begin{array}{l}10 \\
1.6\end{array}$ & $\begin{array}{l}0.5 \\
0.5\end{array}$ & $\begin{array}{l}5.5 \\
1.3\end{array}$ & $\begin{array}{l}81 \% \\
19 \%\end{array}$ \\
\hline 2.3.3. & Precede & $\begin{array}{c}10 \\
4 \\
1.6\end{array}$ & $\begin{array}{l}0.5 \\
0.5 \\
0.5\end{array}$ & $\begin{array}{l}5.5 \\
2.5 \\
1.3\end{array}$ & $\begin{array}{l}59 \% \\
27 \% \\
14 \%\end{array}$ \\
\hline 2.4 & $\begin{array}{l}\text { Still not } \\
\text { precede }\end{array}$ & $\begin{array}{c}10 \\
4 \\
1.6\end{array}$ & $\begin{array}{l}0.5 \\
0.5 \\
0.2\end{array}$ & $\begin{array}{c}5.5 \\
2.5 \\
1.12\end{array}$ & $\begin{array}{l}60 \% \\
27 \% \\
12 \%\end{array}$ \\
\hline
\end{tabular}

Table 6. Data Score of HEP

\begin{tabular}{|c|c|c|}
\hline No & Activity & $\begin{array}{c}\text { Human Error } \\
\text { Probability }\end{array}$ \\
\hline 1.1 .1 & Decelerate & 0.1824 \\
\hline 1.1 .2 & Adding speed & 0.1824 \\
\hline 1.1 .3 & Steady pace & 0.1824 \\
\hline 2.1 & $\begin{array}{c}\text { Check the vehicle } \\
\text { behind }\end{array}$ & 0.1388 \\
\hline 2.2 & $\begin{array}{l}\text { Check the vehicle } \\
\text { in front }\end{array}$ & 0.1388 \\
\hline 2.3 .1 & See rearview & 0.1616 \\
\hline 2.3 .2 & $\begin{array}{c}\text { Turn on the lights } \\
\text { sign }\end{array}$ & 0.00272 \\
\hline 2.3 .3 . & Precede & 1.488 \\
\hline
\end{tabular}

\begin{tabular}{|l|l|l|}
\hline 2.4 & Still not precede & 0.1824 \\
\hline
\end{tabular}

Table 6 obtained by The HEP value is 1,488 , or $149 \%$, the HEP value for this type of error with 2.3 .3 numbers that precede activity with limited time item, the risk does not fit that predicted, and requires a decision that depends on the rider's ability. While the smallest adalahnilai HEP value for this kind of error with 2.3.2 numbers sign that activity turn on the lights with a limited time items and non-functioning lights sign that has a value of 0.00272 or $0.272 \%$.

\section{Conclusion}

Identify the cause of the accident on the largest toll Suramadu method approach SHERPA and methods HEART obtained there are nine activity in the activities of driving, among others Decelerate, Adding speed, Steady pace, checked the vehicle behind, checked the vehicle in front, See rearview, Turn on the lights sign, Precede, Still not precede by HTA. From the results of the identification and analysis using method and HEART SHERPA earned value method biggest HEP is 1,488 or $149 \%$, the HEP value for this type of error with 2.3.3 numbers that precede activity with limited time item, the risk does not fit that predicted, and requires a decision that depends on the ability of the rider so that the necessary improvement in the behavior of motorists to pay attention to safety as a warning to the traffic symbol. While the smallest HEP value is the value for the type of error with 2.3.2 numbers sign that activity turn on the lights with a limited time items and nonfunctioning lights sign that has a value of 0.00272 or $0.272 \%$.

Authors would like to thank University of Trunojoyo Madura in particular the engineering faculty for providing facilities and places for this research. Authors also thanks to all of students at the Ergonomic and Work System Design Research Group for their time and cooperation in completing this paper. For further research, researchers can consider up to the Human reliability assessment method approach based on NASA-TLX, and SWAT.

\section{References}

1. Agus, W., Choirul, B., Aplikasi Human Reliability Assessment sebagai upaya peningkatan kualitas produk batik [Applications Human Reliability Assessment as improving the quality of batik products], Simposium Nasional Teknologi Terapan (SNTT), (2015).

2. Alatas, A. H., \& Putri, R. J., Identifikasi Human Eror Pada Proses Produksi Cassava Chips Dengan Menggunakan Metode SHERPA dan HEART di PT. INDOFOOD FRITOLAY MAKMUR [Identification of Human Error on Cassava Chips Production Process Method Using SHERPA and HEART in PT. INDOFOOD FRITOLAY MAKMUR], Jurnal PASTI, (2017), Page 98-110. 
3. Dhillon, B., Human Reliability with Human Factors, Pergamon Press: Britain, 1(986).

4. Findiastuti, W., Analisa Human Error Dalam Kasus Kecelakaan di Persilangan Kereta Api (Studi Kasus Persilangan Kereta Api 25 Jemur Andayani - Surabaya) [Analysis of Human Error in Case of Accident in Crosses Train (Train Crosses Case Study 25 Jemur Andayani Surabaya)], ITS, (2002), Page 1-7.

5. Handrianto, iridiastadi, Ergonomi Suatu Pengantar [An Introduction to Ergonomics], Bandung: Penerbit PT Remaja Rosdakarya, (2014).

6. Kirwan, B., A Guideto Practical Human Reliability Assessment, Taylor and Francis Group: London, (1994).

7. Kordelia, C.D., Yossyafra, Kurniati, T., Model Kecelakaan Lalu Lintas berdasarkan Korelasi Populasi, Tingkat Pemahaman Pengguna dan Tingkat Pertumbuhan Kendaraan di Kota Besar, Sedang dan Kecil Sumatera Barat [Traffic Accident models based on correlation of population, level of user understanding and Growth Rate Vehicles in Big Cities, Small and Medium West Sumatra], Jurnal Rekayasa Sipil, (2014), (Online). Vol. 10, No. 1, (http://jrs.ft.unand.ac.id/index.php/jrs/ article/download/v10-n1-kordelia/15), 23 Agustus 2019.

8. L.V. Belleghem, S.D. Gasparo and I. Gaillard, "The development of the psychosocial dimension of work," in Constructive ergonomics: A manifesto, chapter 3, Taylor \& Francis, CRC Press, (2006), pp.33-48

9. Lane, R., \&Stanton, N. A., Applying Hierarchical Task Analysis to Medication Administration Errors. Journal Applied Ergonomics, (2006), Page 600-679.

10. Safitri, D., \&Astriaty, A., Human Realiability Assessment dengan Metode Human Error Assessment and Reduction Technique pada Operator Stasiun Shroud PT.X, Jurnal Rekayasa Sistem Industri, (2015), Vol.4 No.1.

11. Sari, R., Pengukuran Beban Kerja Karyawan Menggunakan Metode NASA-TLX di PT. Tranka Kabel [Employee Workload Measurement Method Using NASA-TLX at PT. Tranka Kabel], Jurnal SOSIO-E-KONS, (2017), Vol. 9 No. 3.

12. Spurgin, A., Human Reliability Assessment Theory And Practice, CRC Press Taylor andFrancis Group: United States of America, (2010).

13. Tarwaka, L.H.A. Bakrie, and L. sudiajerng, ERGONOMI untuk Kesehatan, Keselamatan Kerja dan Produktivitas [ERGONOMY for Health, Safety and Productivity]. Cetakan pertama [Fist Edition]. UNIBA Press, (2004).

14. Tayyari, Farriborz, Occupational Ergonomics : Principles and applications, Chapman and Hall, London, (1997).
15. Wignjosoebroto, S., \& Zaini, P., Studi Aplikasi Erginomi Kognitif Untuk Beban Kerja Mental Pilot Dalam Pelaksanaan Prosedur Pengendalian Pesawat dengan Metode SWAT [Study of the Cognitive Erginomi Application For Mental Workload Pilot In Plane Control Procedures Implementation Method with SWAT], (2007), Page 1-10.

16. Wignsoebroto, S., Ergonomi Studi Gerak dan Waktu. Teknik Analisa untuk Peningkatan Produktivitas Kerja [Ergonomics of Motion and Time Studies. Analysis Techniques for Increasing Work Productivity], (2006).

17. William, J., \& Bell, J., Consoliationof The Error Producing Conditions Using in The Human Error Assessment and Reduction Technique (HEART), Journal Safety and Reliability, (2016), Page 26-55.

18. Y. Lémonie, and K. Chassaing, "From the adaptation of movement to the development of gesture," in Constructive ergonomics: A manifesto, chapter 3, Taylor \& Francis, CRC Press, (2006), pp.49-64. 